\title{
Structural Transformation of Agriculture and Poverty in Indonesia
}

\author{
Fitria Ardiansyah ${ }^{1}$, Herman Cahyo Diartho ${ }^{2}$, Endah Kurnia Lestari ${ }^{3}$ \\ Faculty of Economics and Business, Departement of Economics, University of Jember ${ }^{123}$ \\ Email: fitria.ardiansyah@gmail.com
}

https://doi.org/10.30741/wiga.v10i1.513

A R T I C L E I N F O

Date of entry:

17 Januari 2020

Revision Date:

10 February 2020

Date Received:

5 March 2020

\begin{abstract}
A B S T R A C T
The trend of modern development in some countries is the decline in the contribution of the agricultural sector to GDP (gross domestic product), as a consequence of the increased contribution of the non-agricultural sector. So the development strategy that is often applied is to increase the role of the modern sector (industry and services) that have a high level of productivity. The agricultural sector, which has low productivity, often escapes the development strategy, even though the agricultural sector is a place to make a living for some poor people who are in rural areas. This study aims to analyze the effect of economic structural transformation on poverty in Indonesia. The type of data used in this study is quantitative data, in the form of time series data between 1980-2017 obtained from World Bank publications, the World Income Inequality Database, and the Central Statistics Agency. Analysis of the data used is to use VECM estimation to see the short-term relationship and the long-term relationship of each variable. The estimation results of the Vector Error Correction Model (VECM) concluded that in the long run, the agricultural sector has a negative and significant relationship to poverty, while the industrial and service sectors do not have a significant effect on poverty in Indonesia. Per capita income has a positive relationship with poverty in Indonesia. Based on the explanation, it concludes that the policy that must be implemented to overcome the problem of poverty is to develop the agricultural sector.
\end{abstract}

Keywords: Structural Agriculture Transformation, Income Inequality, Poverty, VECM.

\section{INTRODUCTION}

Poverty and income inequality are two things that are part of the Sustainable Development Goals that were endorsed in 2015. Both of these goals are part of the seventeen points that are the goals of the SDGs. Around 767 billion people live in poverty, two-thirds live in rural areas, and the majority of poor people are concentrated in developing countries (FAO; 2017). The agricultural sector accounts for a relatively small share of the global economy but is central to many people's lives. In 2012, the agricultural sector had an economic share of 2.8 per cent of the global economy, employment in this sector was estimated at 19 per cent around 1.3 billion (Alston and Pardey; 2014).

The trend of modern development in some countries is the decline in the contribution of the agricultural sector to GDP (gross domestic product), as a consequence of the increased contribution of the non-agricultural sector (Briones and Felipe; 2013). This tendency occurs due to 
economic growth that occurs continuously, and there are economic sectors that are growing faster than other sectors, resulting in changes in economic structure (structural transformation). Arthur Lewis's structural transformation model explains that economic transformation means a change in economic structure from what was originally a traditional subsistence farming pattern to a modern economic pattern that has an orientation to urban life (Todaro and Smith, 2006). The economic sector in developing countries consists of traditional sectors which are rural subsistence sectors with low productivity and modern urban industrial sectors that have high productivity.

Changes in an economic structure are marked by a decrease in the contribution of the agricultural sector and increased contribution of the industrial sector, both in terms of GDP and in terms of employment. The change occurred due to an increase in output in the modern sector so that it was able to absorb surplus labour from the traditional sector (Romli, 2016). Indicators of a country's economic development progress are often associated with the process of industrialization, the higher the contribution of the industrial sector, the more advanced economic development.

The industrial sector has a high contribution to GDP, but only absorbs a relatively small workforce. Structural transformation that occurred in Indonesia is not balanced (unbalanced transformation), characterized by a decrease in the contribution of the agricultural sector to the formation of GDP faster than the decline in labour (Romli, 2016). This makes a criticism of Arthur Lewis's two-sector model, which cannot explain the phenomenon of unbalanced transformation that occurs in developing countries, including Indonesia. Not all assumptions in the Lewis model are proven, such as assumptions about the profits derived by investors will be reinvested in capitalintensive technology, and the expansion of labour occurs only in the upstream sector so that the industrial sector is unable to absorb surplus labour from the agricultural sector. Another assumption states that the profits obtained by investors are reinvested in the expansion of the domestic industry does not occur. The phenomenon that occurs in Indonesia is a capital flight out of the country (capital flight) so that the domestic industrial sector cannot increase employment opportunities and is unable to absorb surplus labour from the agricultural sector (Romli, 2016).

Furthermore, Nangarumba (2015) explained that the general problem faced by developing countries is to prioritize progress in the industrial sector and tend to leave the agricultural sector. The agricultural sector has many workers with low education. The labour force in the agricultural sector has a high poverty rate. Whereas in developed countries, the development of the industrial and service sectors is able to reduce the level of inequality. This is due to developed countries having high levels of education and the use of technology that is quite rapid so that it can encourage people to work in the industrial sector.

Developing countries have high population growth patterns with an expansion of the workforce that exceeds the absorption capacity of the industrial and service sectors (Andersson and Chaverra; 2015). There are still many workers in developing countries who work in the agricultural sector. The surplus of labour in the agricultural sector cannot be optimally absorbed by the modern industrial sector (Naiya and Manap; 2013). According to Yustika (2014), the agricultural sector is the sector that absorbs the most labour, but this sector in a few years has a growth rate below the rate of economic growth. So that every year the share of the agricultural sector to GDP is decreasing, even though the number of workers who work in the agricultural sector is the most. As a result, the labour surplus from the agricultural sector cannot be directly absorbed, thus exacerbating the problem of unemployment, inequality, and poverty.

In addition to these problems, shifting the workforce from agriculture to bring about rural structural transformation will be important, given a number of recent concerns. These include increasing rural-urban inequality, ageing of rural populations, and growth in agricultural productivity to overcome the scarcity of land and water (Deininger, 2012). According to Bridsall (2007), agricultural growth in the 1970-1980 era in Indonesia could reduce income inequality and 
poverty, because most providers of agricultural production were small farmers, so agricultural growth could reduce rural inequality and poverty.

In theoretical aspects, inequality is a natural thing in the early stages of development (Kuznets; 1955), as a result of the development of the urban industrial sector which is faster than the rural agriculture sector. But in the long run, income inequality will decrease as per capita income rises. The decline in income inequality, according to Kuznets, is due to the large number of workers from the agricultural sector who migrate to the industrial sector. The increase in urban (industrial) population has caused a relatively even distribution of income. So that when described, the relationship between inequality with per capita income growth forms a U-reversed pattern.

Inequality of income does not automatically fall when there is a shift in population from rural to urban areas (urbanization). Chen (2016) suggests the results of different empirical studies. In his analysis, there was a positive relationship between urbanization and rising income inequality. The relationship between economic growth and income inequality proposed by Kuznets did not occur, Kiatrungwilaikun and Suriya (2015) described the pattern of the relationship as U-shaped. Initially, the structural transformation from agriculture to industry increased economic growth and reduced income inequality. But in the period after the Millennium income inequality rose again. This is caused by the development of the digital economy, which makes income inequality rise more widely.

The agricultural labour surplus has a positive relationship with inequality (Andersson and Chaverra, 2015). The intended labour surplus is the difference between the percentage of labour in the agricultural sector and the percentage of value-added. According to Andersson and Chaverra (2015), the solution to reduce income inequality is to increase the contribution of the agricultural sector or by reducing the number of workers in the agricultural sector to be transferred to other sectors. In line with that, Romli, 2016; Susanto, 2013; Sa'diyah 2016; Gonzalez and Resosudarmo, 2016 stated the same thing, that the contribution of the agricultural sector has a negative relationship with inequality.

Kahya (2012), found different things. According to him, the added value of the agriculture and services sectors has a positive relationship with inequality, and this means that the increased contribution of the agriculture and services sectors will further aggravate income inequality while the added value of the industrial sector has a negative relationship with inequality.

Besides affecting the problem of inequality, the structural transformation also affects poverty. Godoy and Dewbre (2010) state that the contribution of the agriculture, services and industry sectors has a negative relationship with poverty. This means that the three economic sectors have a role in reducing poverty. According to Kahya (2012), the industrial and service sectors have a negative relationship with poverty, while the agricultural sector has a positive relationship with poverty. This means that increasing the contribution of the agricultural sector to GDP will further increase poverty levels.

Susanto (2013) found different empirical results. According to him, changes in the agricultural sector have an influence on reducing poverty. Since most of the poor are in rural areas who depend on their income from the agriculture sector, an increase in the contribution of the agricultural sector could ideally improve their welfare. According to Naiya and Manap (2013), the structural transformation has a negative relationship with poverty, but this relationship is not significant. It is precisely income inequality that has a positive relationship to poverty, which means that the level of poverty is also affected by the high-income inequality, the higher the income inequality will worsen the problem of poverty.

The phenomenon of unbalanced structural transformation occurring in Indonesia results in income inequality. The problem of income inequality occurs because of differences in different sectoral 
growth. The agricultural sector has a relatively large number of workers while the value of its contribution to GDP will lead to lower productivity than this sector. This has an impact on low income earned from work in the agricultural sector. This is different from the industrial sector, which has contributed to the formation of relatively high GDP with a small number of workers, automatically workers in the sector have higher wage levels. This difference in sectoral income levels will further trigger high-income inequality.

Inequality of income in Indonesia is relatively high, and this relatively high-income inequality is a problem in economic development because the economic growth achieved cannot be enjoyed by all people, only a few people enjoy it (Romli, 2016).

In addition to influencing unbalanced transformation income inequality, it also affects poverty. The agricultural sector, which has been the source of livelihood for the rural poor, has a lower sectoral growth rate than other sectors. The percentage of poor people has decreased every year, in 2010 the number of poor people was $11.96 \%$ this number had decreased to $10.12 \%$ in 2017 . However, the number of poor people was mostly in rural areas, in 2017, the poor population in rural areas $61.36 \%$ and in urban areas $38.6 \%$ (BPS, 2019).

Economic growth needs to be directed toward effective economic sectors to reduce poverty and create income distribution. Understanding the direction of structural transformation is important in order to find out which economic sectors are effective in overcoming the agricultural sector labour surplus and also effective in reducing poverty and income inequality. Therefore, there is a need for government intervention in economic development planning, especially to develop economic sectors that are not only a driving force for economic growth but also have benefits to reduce poverty and income inequality in Indonesia.

Based on the background above, there are several structural transformation issues

in Indonesia. This is related to the unbalanced transformation process between the economic structure in the agricultural sector and the number of its workforce. The industrial sector, which has a large contribution to GDP has a relatively low ability to absorb labour. There is some debate about the pattern of relationships between structural transformation and income inequality and poverty, based on the results of previous empirical studies. The problem in this study is how the effect of economic structural transformation on poverty in Indonesia

\section{RESEARCH METHODS}

The research design that will be used in this study uses a quantitative approach. The quantitative approach focuses its analysis on numerical data (numbers) that are processed by statistical methods. Basically, this approach is used in inferential research (in the context of testing hypotheses) and draws conclusions from research on a probability of rejecting a null hypothesis. With quantitative methods obtained the significance of group differences or the significance of the relationship between the variables studied (Azwar, 2003).

The type of data used in this study is quantitative data in the form of time series data between 1980-2017. The use of this time span is to see the phenomenon of economic structural transformation in Indonesia. The structural transformation of the economy is a stage of development, so it requires a long period of time to examine the phenomenon. Data sources used in this study are secondary data, obtained from World Bank publications, the World Income Inequality Database, and the Central Statistics Agency.

The data analysis method used to answer the purpose of this study is to use Vector Autoregression analysis to analyze the effect of economic structural transformation on poverty in Indonesia. By 
using the model used by Kahya (2012); Godoy and Dewbre (2010); Alfarabi (2014), here is the equation model: Poverty $=\beta_{0}+\beta_{1} P+\beta_{2} I+\beta_{3} J+\beta_{4} I n+\mathrm{e}$

Answering the purpose of the study used the Vector Autoregression (VAR), model. The model explains that each equation is made based on the number of variables used. Each variable is treated the same so that the VAR model does not care about exogenous and endogenous variables, because each variable is treated equally. The specifications of the VAR model used are as follows:

$$
\begin{aligned}
\text { Poverty }_{t}= & \sum_{i=1}^{n} \beta_{i 1} P_{t-i}+\sum_{i=1}^{n} \lambda_{i 1} I_{t-i}+\sum_{i=1}^{n} \mu_{i 1} \text { Poverty }_{t-i}+\sum_{i=1}^{n} \gamma_{i 1} J_{t-i} \\
& +\sum_{i=1}^{n} \varepsilon_{i 1} I_{t-i}+u_{1 t}
\end{aligned}
$$$$
\begin{gathered}
P_{t}=\sum_{i-1}^{n} \beta_{i 2} P_{t-i}+\sum_{i=1}^{n} \lambda_{i 2} I_{t-i}+\sum_{i-1}^{n} \mu_{i 2} \text { Poverty }_{t-i}+\sum_{i-1}^{n} \gamma_{i 2} J_{t-i}+\sum_{i=1}^{n} \varepsilon_{i 2} I_{t-i} \\
+u_{2 t}
\end{gathered}
$$$$
I_{t}=\sum_{i=1}^{n} \beta_{i 3} P_{t-i}+\sum_{i=1}^{n} \lambda_{i 3} I_{t-i}+\sum_{i=1}^{n} \mu_{i 3} \text { Poverty }_{t-i}+\sum_{i=1}^{n} \gamma_{i 3} J_{t-i}+\sum_{i=1}^{n} \varepsilon_{i 3} \operatorname{In}_{t-i}
$$$$
+u_{3 t}
$$$$
I_{t}=\sum_{i=1}^{n} \beta_{i 4} P_{t-i}+\sum_{i=1}^{n} \lambda_{i 4} I_{t-i}+\sum_{i=1}^{n} \mu_{i 4} \text { Poverty }_{t-i}+\sum_{i=1}^{n} \gamma_{i 4} J_{t-i}+\sum_{i=1}^{n} \varepsilon_{i 4} I_{t-i}
$$$$
+u_{4 t}
$$$$
\operatorname{In}_{t}=\sum_{i=1}^{n} \beta_{i 5} P_{t-i}+\sum_{i=1}^{n} \lambda_{i 5} I_{t-i}+\sum_{i=1}^{n} \mu_{i 5} \text { Poverty }_{t-i}+\sum_{i=1}^{n} \gamma_{i 5} J_{t-i}
$$$$
+\sum_{i=1}^{n} \varepsilon_{i 5} \ln _{t-i}+u_{5 t}
$$

Information: P: the added value of the agricultural sector, I: added value to the industrial sector, A: value-added service sector, In: Per capita income, Poverty: Poverty, u_1t, u_2t, u_3t, u_4t, u_5t are error terms that are assumed to be uncorrelated

\section{RESULTS AND DISCUSSION}

Based on the results of the cointegration test, it is known that there is cointegration between the research variables so that the appropriate analysis model to use is the VECM model. VECM estimation is used to show the short-term relationship with the long-term relationship between variables. This study uses a significance level of five per cent, with at-count of 1.696. If the tstatistic value is greater than 1.696 , the variable has a significant effect. 
VECM estimation results regarding the effect of structural transformation on income inequality are as follows:

Table 1. Short-Term VECM Estimation Results Effects of Structural Transformation on Income Inequality

\begin{tabular}{ccc}
\hline Variable & Coefficient & T-Statistics \\
\hline CointEq1 & 0.037 & 0.268 \\
D(POV(-1)) & -0.749 & $-2.052^{*}$ \\
D(POV(-2)) & -0.516 & -1.279 \\
D(POV(-3)) & 0.162 & 0.375 \\
D(P(-1)) & -3.123 & -1.189 \\
D(P(-2)) & -1.735 & -0.686 \\
D(P(-3)) & 0.792 & 0.336 \\
D(J(-1)) & 0.071 & 0.048 \\
D(J(-2)) & 0.351 & 0.303 \\
D(J(-3)) & 0.166 & 0.171 \\
D(I(-1)) & -0.481 & -0.482 \\
D(I(-2)) & 0.266 & 0.300 \\
D(I(-3)) & 0.078 & 0.096 \\
D(IN(-1)) & -0.554 & -0.225 \\
D(IN(-2)) & -1.376 & $-1.815^{*}$ \\
D(IN(-3)) & 0.124 & 0.119 \\
C & -5.274 & -1.963 \\
\hline
\end{tabular}

Source: Eviews Results 7

Based on the short-term VECM estimation, it is known that the poverty variable is also influenced by the variable itself in the previous year (POV (-1), with a t-statistic value of $-2,052$ whose value is greater than t-arithmetic, This means that when the percentage of the population is poor the previous year rose by one per cent, then the poverty rate in the year is now down by $0.74 \%$. The variable that has a significant influence on poverty, namely the variable income per capita (IN (2)) which has an at-statistic value of -1.181 or greater than the value. This means that the increase in per capita income in the previous two years by one per cent will reduce the number of poor people by 1.376 per cent, and the long-term VECM estimation results regarding the effect of economic structural transformation on poverty are as follows:

Table 2. Results of Long-Term VECM Estimates Effect of Structural Transformation on Income Inequality

\begin{tabular}{ccc}
\hline Variable & Koefisien & t-Statistik \\
\hline P(-1) & -4.501 & $-3.577^{*}$ \\
J(-1) & 0.548 & 0.198 \\
I $(-1)$ & -1.391 & -0.872 \\
IN(-1) & 4.065 & $3.794^{*}$ \\
\hline
\end{tabular}

Source: Eviews Results 7

Based on the long-term VECM estimation results show that there are two variables that have a significant influence on poverty with a t-statistic value greater than the t-count value of 1.696 . The long term VECM estimation results are as follows: a. The Influence of the Contribution of the Agriculture Sector $(\mathrm{P})$ to Poverty (POV). P variable has a negative and significant effect on POV with a value of $-4,501$. If there is an increase in the contribution of the agricultural sector by one per cent in the previous year, then poverty will decrease by 4.501 per cent in the current year. $b$. Effect of income per capita (IN) on poverty. The IN variable has a negative and significant effect on POV. If per capita income rose by one per cent in the previous year, it would cause poverty to decrease by 1.982 per cent in the current year. 
After estimating VECM, the next step that will be carried out is the Impulse Response Function (IRF). IRF illustrates the effect of shock or shock from endogenous variables to other endogenous variables contained in a model. In this study, the IRF will describe the influence of the interrelationships between income inequality, poverty, agricultural sector, industry, service, and per capita income.

The effect of shock is illustrated by the movement of the graph on the results of the IRF test, and when shock occurs, it will be known the period of time the variable responds to the shock that arises to its equilibrium point. The IRF coefficient value describes information about the response of one endogenous variable to a change of one standard deviation on all endogenous variables. IRF testing is carried out using a period of 32 based on the wishes of researchers to determine the response between variables.

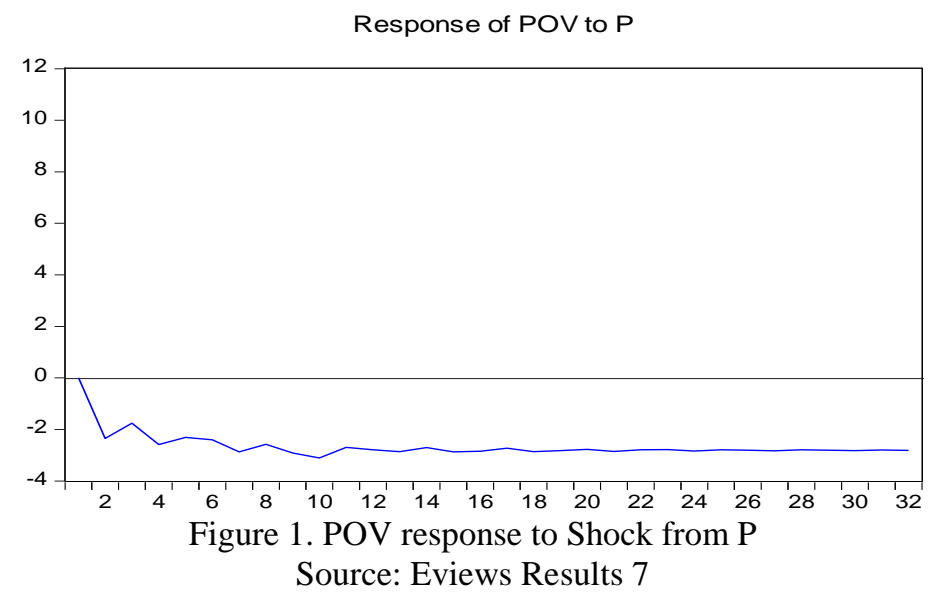

The POV variable gives a response to the turmoil of the $\mathrm{P}$ variable in the second period of zero. In the 3rd period the POV variable responds negatively to the turmoil of the $\mathrm{P}$ variable, the 4th to 17 th period of the POV variable fluctuates its value is still negative. The balance occurred in the 18th period marked by the absence of turmoil from the variable $\mathrm{P}$.

Response of POV to J

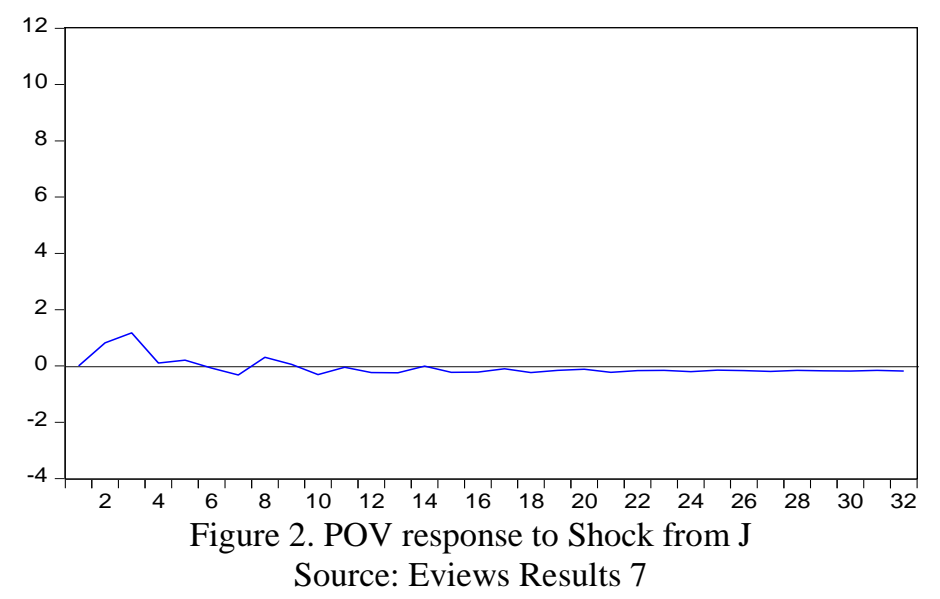

The shock of variable $\mathrm{J}$ is responded positively by the POV variable in the first to the third. In the 4th to 8 th period POV gives a negative response to the shock of the variable J. In the next period, 
the POV response to the $\mathrm{J}$ shock starts to decrease, the value is negative. The response will reach a balance in the 18 th period.

Response of POV to I

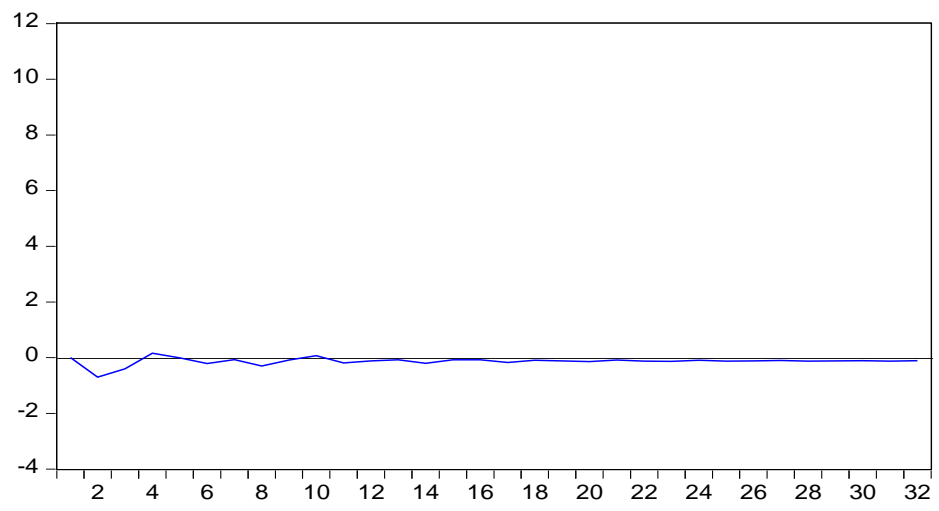

Figure 3. POV response to Shock from I

Source: Eviews Results 7

POV response to a variable I shock is fluctuating and negative. The second period of the POV variable has not yet responded, only in the third period has the POV response to shock begun to decline, but in subsequent periods it has risen again. Fluctuations in POV response to shock occur until the 12th period, in the 14th period the POV variable reaches balance. This is indicated by the non-fluctuation of POV response to shock from variable I the value of POV variable response is negative.

Response of POV to IN

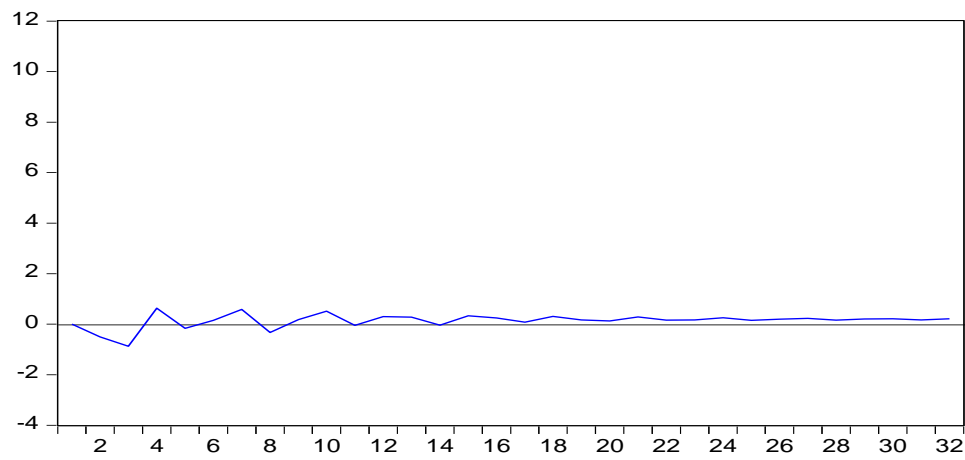

Figure 4. The response of POV to Shock from IN

Source: Eviews Results 7

The POV response to shocks from the IN variable fluctuates and has a negative value at the beginning of the period. There was a surprise in the 4th period that the POV variable responded positively. In the next period, the response of the POV variable fluctuates until it reaches a balance point in the 17th period, the response of the POV variable is positive.

In addition to being described in the form of IRF the proportion of the contribution of endogenous variables in the VAR model that responds to shock or shocks is also described in the form of VD (Variance Decomposition). The difference between IRF and VD is in the form of appearance, in IRF variable movement is depicted in graphical form, but in VD variable movement is described in per cent units. 
Table 3. Analysis of Variance Decomposition of Poverty in Indonesia

\begin{tabular}{|c|c|c|c|c|c|c|}
\hline \multirow[b]{2}{*}{ Period } & \multicolumn{5}{|c|}{ Variance Decomposition of POV: } & \multirow[b]{2}{*}{ IN } \\
\hline & S.E. & POV & $\mathbf{P}$ & $\mathbf{J}$ & I & \\
\hline 1 & 7.993514 & 100.0000 & 0.000000 & 0.000000 & 0.000000 & 0.000000 \\
\hline 2 & 8.802525 & 91.05435 & 7.113502 & 0.873537 & 0.636378 & 0.322237 \\
\hline 3 & 9.647499 & 86.76889 & 9.239518 & 2.206693 & 0.700189 & 1.084711 \\
\hline 4 & 10.46063 & 82.24147 & 13.96132 & 1.886489 & 0.618936 & 1.291784 \\
\hline 5 & 10.80029 & 78.70285 & 17.67398 & 1.807460 & 0.580624 & 1.235087 \\
\hline 6 & 11.44969 & 76.59661 & 20.12532 & 1.612556 & 0.549829 & 1.115680 \\
\hline 7 & 12.34838 & 74.17617 & 22.71077 & 1.452591 & 0.475704 & 1.184760 \\
\hline 8 & 12.84643 & 71.92721 & 25.01901 & 1.399550 & 0.494489 & 1.159742 \\
\hline 9 & 13.44778 & 69.64955 & 27.53901 & 1.278847 & 0.455243 & 1.077354 \\
\hline 10 & 14.01496 & 66.97341 & 30.25304 & 1.224371 & 0.422055 & 1.127125 \\
\hline 11 & 14.41410 & 65.25448 & 32.10477 & 1.158333 & 0.415997 & 1.066415 \\
\hline 12 & 14.96754 & 64.23605 & 33.24282 & 1.099485 & 0.391771 & 1.029873 \\
\hline 13 & 15.44844 & 62.93367 & 34.64113 & 1.055964 & 0.370160 & 0.999074 \\
\hline 14 & 15.83238 & 61.78615 & 35.88825 & 1.005397 & 0.368399 & 0.951808 \\
\hline 15 & 16.29940 & 60.78114 & 36.96163 & 0.967903 & 0.349783 & 0.939543 \\
\hline 16 & 16.70476 & 59.72456 & 38.08487 & 0.939248 & 0.335203 & 0.916121 \\
\hline 17 & 17.08695 & 58.94473 & 38.94625 & 0.901359 & 0.330009 & 0.877646 \\
\hline 18 & 17.52710 & 58.26175 & 39.68269 & 0.874072 & 0.316208 & 0.865278 \\
\hline 19 & 17.90488 & 57.49831 & 40.51087 & 0.845458 & 0.307040 & 0.838318 \\
\hline 20 & 18.27391 & 56.87839 & 41.19529 & 0.815740 & 0.300869 & 0.809709 \\
\hline 21 & 18.66728 & 56.29466 & 41.81885 & 0.796266 & 0.290223 & 0.800009 \\
\hline 22 & 19.01695 & 55.71258 & 42.45123 & 0.774442 & 0.283718 & 0.778026 \\
\hline 23 & 19.37381 & 55.25292 & 42.95930 & 0.752363 & 0.278123 & 0.757295 \\
\hline 24 & 19.73827 & 54.79570 & 43.45203 & 0.735769 & 0.270318 & 0.746177 \\
\hline 25 & 20.07154 & 54.33703 & 43.95310 & 0.716936 & 0.265419 & 0.727512 \\
\hline 26 & 20.41363 & 53.95201 & 44.37573 & 0.699620 & 0.260062 & 0.712578 \\
\hline 27 & 20.75365 & 53.56570 & 44.79243 & 0.685741 & 0.253944 & 0.702177 \\
\hline 28 & 21.07438 & 53.19982 & 45.19313 & 0.670243 & 0.249879 & 0.686931 \\
\hline 29 & 21.40276 & 52.88392 & 45.53911 & 0.656407 & 0.245192 & 0.675373 \\
\hline 30 & 21.72367 & 52.56170 & 45.88833 & 0.644235 & 0.240443 & 0.665286 \\
\hline 31 & 22.03250 & 52.25984 & 46.21912 & 0.631280 & 0.236933 & 0.652823 \\
\hline 32 & 22.34617 & 51.98938 & 46.51413 & 0.620027 & 0.232856 & 0.643608 \\
\hline
\end{tabular}

Source: Eviews Results 7

In the first period, the poverty variable is affected by the shock of the poverty variable itself, and all the variables have not given a shock. The contribution of the agricultural sector $(\mathrm{P})$ has the greatest influence on poverty with a shock value of $7.11 \%$; shock value of the contribution of the service sector $(\mathrm{J})$ of $0.87 \%$; The contribution of the industrial sector (I) was $0.63 \%$; and variable income per capita (IN) gives a shock of $0.32 \%$ in the second period. $\mathrm{P}$ variable has the biggest influence on POV in the first period, then has a tendency to increase the value of shock in the next period. In the second period, the shock of the variable $\mathrm{P}$ had a tendency to increase until the end of the period, the 32 nd period, and the shock value was $46.51 \%$.

Variable $\mathrm{J}$ has a tendency that the shock value decreases from the 3 rd period of $2.20 \%$ to the end of the period, whose value is $0.62 \%$. This also happened to variable I, which has a tendency of shock that decreases every year in the 3rd period the value of $0.70 \%$ fell to $0.23 \%$ in the 32 nd period. The POV variable itself gives a shock to the POV variable, the highest shock value in the first period of $100 \%$. In the next period until the end of the 32nd period, the POV variable has decreased to $51.98 \%$ in the last period. IN variable at the beginning of the period, the shock value 
increased to the 4 th period of $1.94 \%$ than in the next period experienced a downward trend until the end of the period to $0.64 \%$.

In testing using the estimation of the short-term VECM model regarding the effect of economic structural transformation on poverty, the results show that only the IN variable (per capita income) has a negative and significant relationship to poverty. Per capita income is a parameter of community welfare when per capita income rises, and the community is able to meet their basic needs so that poverty will automatically decrease (Azizah, 2018) while the variables $P$ (contribution of the agricultural sector), I (contribution of the industrial sector), and $\mathrm{J}$ (contribution of the service sector) do not have a significant effect on poverty.

The results of the long-term VECM estimation variable contribution of the agricultural sector (P), and income per capita (IN) have a significant effect on poverty. The agricultural sector has a large role in overcoming the problem of poverty, and this is consistent with the results of estimates that the agricultural sector has a negative relationship with poverty. These results are consistent with Romli's (2016) study; Rehman (2016), which states that the contribution of the agricultural sector has a negative relationship to poverty. The majority of the poor live in rural areas that depend on their income from the agricultural sector, so improving the performance of the agricultural sector will reduce the number of poor people (Todaro and Smith, 2006).

The agricultural sector should ideally receive more attention from the government in order to increase the growth of the agricultural sector to reduce the number of poor people. The development of the agricultural sector has three main objectives, firstly to increase income through the growth of the agricultural sector which will directly increase its productivity, secondly to equalize the growth of the agricultural sector by focusing on small farmers, and the third is to maintain the sustainability of the agricultural sector which has a focus on environmental problems (Rehman, 2016).

The contribution of the service sector ( $\mathrm{J}$ ) and industry (I) has an insignificant relationship to poverty. The service sector and industry have the largest contribution to the formation of GDP; in fact, can not reduce poverty. In Arthur Lewis's structural transformation theory, they are explaining that a shift in economic activity from (traditional) agriculture to the industrial and service sectors (modern) will increase its productivity (Boyd, 2007). But apparently, in the Indonesian context, this does not apply, the service sector, which is a modern sector, is not effective in reducing poverty. This happens because the transformation of labour in Indonesia does not occur optimally; the number of agricultural sector workers per year is reduced. Workers in the agricultural sector mostly switch to the informal sector, so the proportion of the number of workers in the informal sector increases. This phenomenon occurs because of the low level of education of the workforce in Indonesia (Anwar, 2014).

Per capita income has a positive relationship with poverty. The increasing income per capita in Indonesia has no benefit for the poor because the growth of income per capita only increases the income of a part of the population. Inequality in land ownership and education level makes per capita income growth less able to reduce the number of poor people because most of the benefits of income growth are only enjoyed by residents who have high levels of education and landowners (Department for International Development, 2008).

Based on the results of the IRF and VD analysis, the variable that has the most influence on poverty is the contribution of the agricultural sector, so that efforts that have been made to reduce poverty are by increasing the productivity of the agricultural sector. Increasing the productivity of the agricultural sector is prioritized to the agricultural sector that has a small scale or to farmers who have little land, other than that what can be done is to shift the activity of subsistence agriculture into commercial agriculture so as to improve its welfare (World Bank, 2007). 


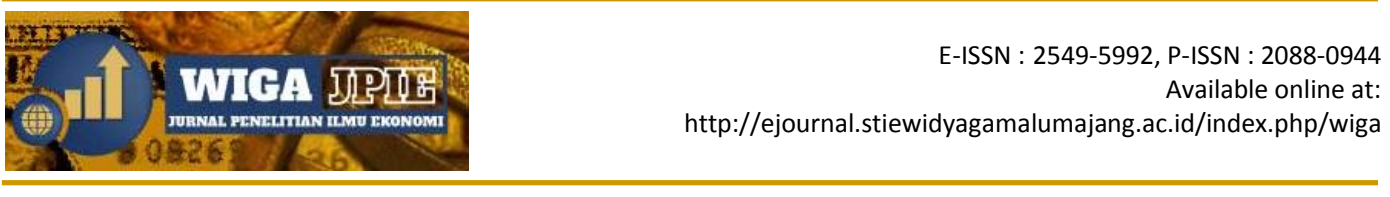

\section{CONCLUSION}

Testing the relationship of structural transformation of the economy to poverty in Indonesia using the Vector Error Correction Model (VECM) concluded that in the long run, the agricultural sector has a negative and significant relationship to poverty, while the industrial and service sectors do not have a significant effect on poverty in Indonesia. Per capita income has a positive relationship with poverty in Indonesia. Based on the explanation, it is concluded that the policy that must be taken to overcome the problem of poverty is to develop the agricultural sector. The increase in income per capita must reflect an increase in the income of the poor, who are usually located in rural areas and mostly work in the agricultural sector.

\section{REFERENCE}

Acquah, H. D. G. 2010. Comparison of Akaike Information Criterion (AIC) and Bayesian Information Criterion (BIC) in Sekection of an Asymetric Price Relationship. Journal of Development and Agricultural Economics Vol. 2 (1): hlm. 01-06

Alfarabi, M. A. Perubahan Struktur Ekonomi dan Dampaknya terhadap Kemiskinan di Provinsi Jambi. Jurnal Perspektif Pembiayaan dan Pembangunan Daerah Vol. 1 No. 3.

Alston, J. M. dan Pardey, P. G. 2014. Agriculture in the Global Economy. Journal of Economic Perspectives Vol 28: pages 121-146.

Andersson, M. P. dan Chaverra, A. F. 2015. Structural Change and Income Inequality: Agricultural Development an Intersectoral Dualism in the Developing World 1960-2010. Oasis 23: hal 99-122.

Andiny, P. dan Mandasari, P. 2017. Analisis Pertumbuhan Ekonomi dan Kemiskinan terhadap Ketimpangan di Provinsi Aceh. Jurnal Penelitian Ekonomi Akutansi Vol. 1, No. 2.

Azizah, E. W. 2018. Pengaruh Pendidikan, Pendapatan Perkapita dan Jumlah Penduduk Terhadap Kemiskinan di Provinsi Jawa Timur. Jurnal Ilmu Ekonomi. Vol. 2. Jilid 1.

Bridsall, N. 2007. Income Distribution: Effects on Growth and Development. Working Paper no. 118.

Briones, R dan Felipe, J. 2013. Agriculture and Structural Transformation in Developing Asia: Review and Outlook. Asian Development Bank No. 363.

Chen, G. 2016. Urbanization and Income Inequality in Post-Reform China: A Causal Analysis Based on Time Series Data. Public Library of Science 11 (07).

Deininger, K. 2012. Moving off the Farm: Land Institutions to Facilitate Structural Transformation and Agricultural Productivity Growth in China. Policy Research Working Paper 5949.

FAO. 2017. Ending Poverty and Hunger by Investing in Agriculture and Rural Areas. Food and Agriculture Organization of the Unuted Nations.

Gonzalez, I. dan Resosudarmo, B. P. 2016. A Sectoral Growth-Income Inequality Nexus in Indonesia. Working Paper in Trade and Development No. 2016/15.

Kahya, M. 2012. Structural change, income distribution and poverty in ASEAN-4 countries. Tesis. Swedia: Master Progamme in Economics Growth Lund University.

Kiatrungwilaikun, N dan Suriya, K. 2015. Rethinking Inequality and Growth: The Kuznets Curve after the Millennium. International Journal of Intelligent Technologies and Applied Statistics Vol.8, No.2 hal. 159-169.

Kuznets, S. 1955. Economic Growth and Income Inequality. The American Economic Review Volume XIV no. 1.

Lewis, W. A. 1977. The Evolution of the International Economic Order. Discussion Paper no. 7. https://www.princeton.edu/rpds/papers/WP_74.pdf. [diakses pada 15 November 2016].

Naiya, I. I. dan Manap T. A. A. 2013. Structural Transformation, Poverty and Inequality in Nigeria: An ARDL Bound Testing Technique. International Journal of Economics and Finance Vol. 5, No. 4. 
Nangarumba, M. 2015. Analisis Pengaruh Struktur Ekonomi, Upah Minimum Provinsi, Belanja Modal, dan Investasi terhadap Ketimpangan Pendapatan di Seluruh Provinsi di Indonesia Tahun 2005-2014. Jurnal Ekonomi dan Studi Pembangunan Vol. 7, No. 2.

Romli, M. S. 2016. Transformasi Struktural: Faktor-faktor dan Pengaruhnya terhadap Disparitas Pendapatan di Madura. Jurnal Ekonomi dan Kebijakan Pembangunan Vol. 5 No. 1, hlm: 25-44.

Suparmoko, M. 2005. Pertumbuhan Ekonomi, Distribusi Pendapatan dan Lingkungan. UNISIA No. 57/XXVIII/III/2005.

Susanto, R. D. 2013. Dampak Perubahan Struktural Sektor Pertanian terhadap Kemiskinan dan Kesempatan Kerja di Indonesia. Jurnal Perencanaan Pembangunan Vol. 1 No. 19

Todaro, M. P. dan Smith, S. C. 2006. Economics Development. Ninth Edition. United Kingdom: Pearson Education Limited. Terjemahan oleh Munandar, Haris dan Puji, A. L. 2006. Pembangunan Ekonomi. Penerbit Erlangga

World Bank. 2016. World Development Indicators. http://data.worldbank.org/country/indonesia. [Diakses pada 20 November 2016].

Yustika, A. E. 2014. Pembangunan dan Trilogi Ketimpangan. Dalam Perekonomian Indonesia: Memahami Masalah dan Menetapkan Arah. Malang: Selaras. https://www.princeton.edu/rpds/papers/WP_5.pdf. [diakses pada 15 November 2016].

2019. World Development Indicators. http:data.worldbank.org/country/indonesia. [Diakses pada 17 Maret 2019]. 